J. Clin. Chem. Clin. Biochem.

Vol. 20, 1982, pp. $731-734$

\title{
Insulin Binding to Erythrocytes After Acute 16-Methyleneprednisolone Ingestion
}

\author{
By A. Dwenger, W. Holle, R. Zick and I. Trautschold
}

Abteilung für Klinische Biochemie des Zentrums Biochemie und Arbeitsbereich Diabetologie des Zentrums Innere Medizin, Medizinische Hochschule Hannover

(Received February 15/May 28, 1982)

Summary: The binding of $\left[{ }^{\mathbf{1 2 5}} 1\right]$ insulin to erythrocytes, glucose and insulin were determined before and 1,7 and 35 days after ingestion of $2 \times 60 \mathrm{mg}$ 16-methyleneprednisolone. None of two groups of volunteers (7 males, 4 females) showed clear alterations of the insulin binding parameters $\left(\mathrm{K}_{\mathrm{a}}\right.$ and $\left.\mathrm{R}_{\mathbf{0}}\right)$, or of the fasting cortisol, glucose and insulin concentrations.

These results exclude the possibility that the diabetogenic effect of glucocorticoids is accompanied by an alteration of the insulin receptor characteristics of erythrocytes.

\section{Insulinbindung an Erythrocyten nach akuter Gabe von 16-Methylen-prednisolon}

Zusammenfassung: Die Bindung von [ $\left.{ }^{125} \mathrm{I}\right]$ Insulin an Erythrocyten sowie die Konzentrationen von Cortisol, Glucose und Insulin im Plasma wurden vor und 1, 7 und 35 Tage nach Gabe von $2 \times 60$ mg 16-Methylen-prednisolon ermittelt. In keinem Falle (7 Männer, 4 Frauen) konnten deutliche Änderungen der Insulin-Bindungsparameter sowie der Nüchtern-Cortisol-, -Glucose- und -Insulin-Konżentrationen beobachtet werden.

Die vorliegenden Ergebnisse schließen aus, daß die diabetogene Wirkung von Glucocorticosteroiden an einer Änderung der Characteristika der Insulin-Rezeptoren von Erythrocyten erkannt werden kạnn.

\section{Introduction}

Glucocorticoid administration is known to produce insulin resistance (1) and it has been suggested that the diabetogenic effect of corticosteroids might be mediated, at least in part, via changes in insulin receptors (2). Until now quite different results on the effect of glucocorticoids on insulin binding have been reported $(2,3,5,9)$. There.fore insulin binding on erythrocytes was studied in normal volunteers after an ạcute high-dose steroid treatment which is currently being used clinically in man.

\section{Materials and Methods}

\section{Subjects}

Two groups of subjects were investigated:
(A) 7 healthy males and
(B) 4 healthy females.

Each of them received each $60 \mathrm{mg}$ of 16-methyleneprednisolone (Decortilen, Merck) at two successive days. Heparinized blood samples were drawn by venipuncture in the fasting state before steroid ingestion as well as 24 hours after the second dosage, 7 days later and after 5 weeks.

\section{Insulin binding studies}

Insulin binding was performed according to the procedure of Gambhir (6) with slight modifications (4). Isolated erythrocytes $\left(3.5-4.5 \cdot 10^{12} / 1\right)$ were incubated with [ ${ }^{125}$ I]insulin $(0.05 \mathrm{nmol} / \mathrm{l})$ and additionally with unlabeled insulin $(0.09-$ $174 \mathrm{nmol} / \mathrm{l}$ ) at $15^{\circ} \mathrm{C}$ for 3 hours; nonspecific binding was determined in the range between 0.5 and $17.4 \mu \mathrm{mol} / 1$ of unlabeled hormone and an average was subtracted from total binding to give specific insulin binding.

\section{Analy tical procedures}

Insulin (7) and cortisol (Amersham/Buchler) were determined radioimmunologically, glucose was measured by the glucose oxidase method (Boehringer/Mannheim). 


\section{Calculation procedures}

In view of our recent finding of a critical ligand concentration (8), the analysis of binding data was performed on the initial part of the Scatchard plot up to a total ligand concentration of about $2 \mathrm{nmol} / 1$. Individual Scatchard plots were made for each subject, and receptor affinity and concentration were calculated from the initial points of the Scatchard plot by linear regression methods. Statistical analyses were carried out using the Wilcoxon test for paired data. From the total binding data, the analytical, the intra- and the interindividual variances were calculated.

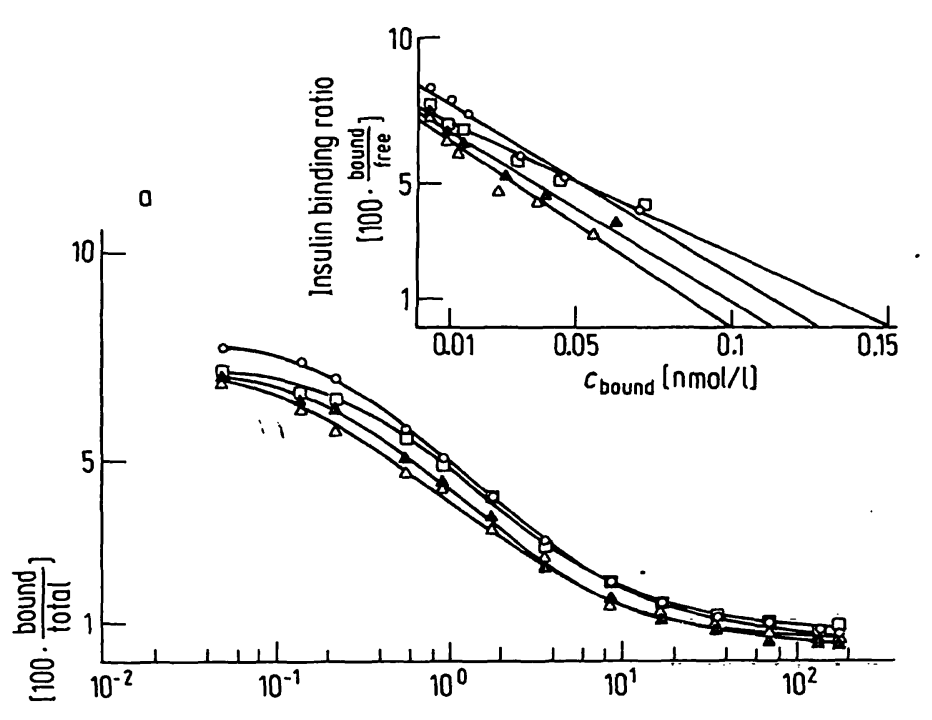

Tab. 1. Significance of differences in erythrocyte insulin receptor affinity $\left(K_{2}\right)$ and concentration $\left(R_{0}\right)$ before $(0)$ and after $(1,7,35$ days) administration of 16-methyleneprednisolone calculated by. Wilcoxon's test for paired data.
After an acute glucocorticoid treatment no significant changes of the erythrocyte insulin receptor affinity and concentration could be observed 1,7 and 35 days after ingestion of the steroid in males (fig. 1'and 2, tab. 1).

Endogenous cortisol tended to decrease one day after steroid administration and to increase afterwards whereas insulin seemed to be slightly elevated after one day followed by a normalization, but none of the differences were significant. Plasma glucose levels, too, did not exhibit significant changes (fig. 3). In females there were slight differences in $K_{a}$ between days 7 and 35 as well as in $R_{0}$ between days 1 and 35 and between days 7 and 35 . But these differences could be calculated only for $p<0.2$ (fig. 2 and tab. 1). Plasma cortisol, insulin and glucose concentrations did not change significantly in females (fig. 3).

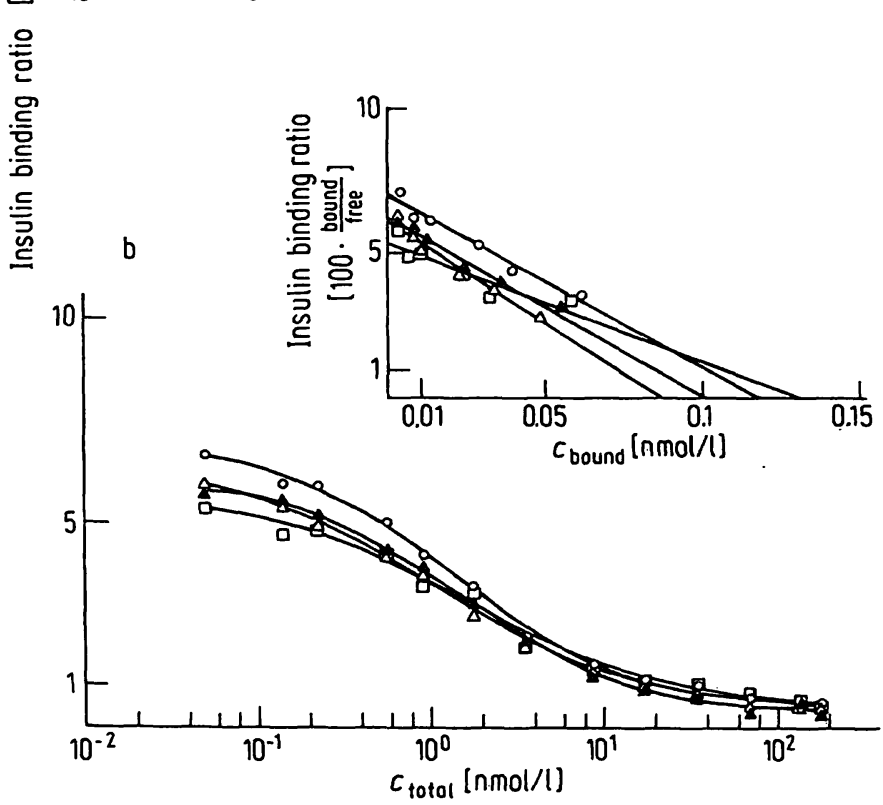

Fig. 1. Specific insulin binding to human erythrocytes $\left(4 \cdot 10^{12} / 1\right)$ before $(\Lambda)$ as well as 1 day (o), 7 days $(\square)$ and 35 days $(\Delta)$ after administration of $2 \times 60 \mathrm{mg} \mathrm{16-methyleneprednisol-}$ $\left.{ }^{125} \mathrm{I}\right]$ insulin binding $\left(\frac{\mathrm{B}}{\mathrm{T}}\right)$ in dependence on the total insulin concentration ( $\mathrm{nmol} / \mathrm{l})$. $\mathrm{a}=$ means of the data from 7 males $b=$ means of the data from 4 females Insets: Scatchard plots derived from the corresponding binding data; slopes of the straight lines (linear regression up to $2 \mathrm{nmol} / \mathrm{l}$ ) indicate receptor affinity; intercepts with the abscissa indicate the maximal amount of insulin bound.
Analysis of variances was performed for the lower $(0.05-$ $2 \mathrm{nmol} / 1)$ and the higher (17.4-17.4 $\mathrm{nmol} / 1)$ ranges of total ligand concentrations separately. The analytical variances were $4-10 \% \mathrm{CV}$ for the lower range, $19-44 \%$ $\mathrm{CV}$ for the higher range; the corresponding data for the intraindividual variances were $12-21 \%$ and $37-56 \%$, and for the interindividual variances $45-47 \%$ and $58-$ $65 \% \mathrm{CV}$.

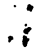




\section{Discussion}

By employment of a modified Scatchard analysis (8), the current results show no modulation of the erythrocyte insulin receptor after 16-methyleneprednisolone administration. This is in agreement with the results of Fantus et al. (9) who did not find any alteration on monocyte insulin receptors after prednisone ingestion. In contrast, Yasuda et al. (5) reported a decrease of the receptor affinity on erythrocytes and Beck-Nielsen et al. (3) found an increase of the receptor concentration on monocytes. These contradictary results can be partially explained by the individual data handling of each investigator (4). There are slight differences of the experimental procedures, like the size of the corticosteroid doses and the time of blood withdrawal after steroid ingestion. But these should influence the degree rather than the quality of alterations of the receptor.
Receptor binding data were calculated from the terminal part of the Scatchard plot. As can be seen by the analysis of variances one would expect sufficient reliability of the results only from data in the lower range of total ligand concentrations, i.e. from the initial part of the Scatchard plot. We demonstrated that the binding parameters $K_{a}$ and $R_{0}$ calculated from the initial part of the Scatchard plot (up to total ligand concentrations representing the half maximal inhibition concentration of the system) were nearly identical with those calculated by employment of a non-linear least squares method (8). Therefore we focused our calculation on the initial part of the Scatchard plot.

Our results exclude the possibility that the diabetogenic effect of glucocorticosteroids is reflected in alterations of the erythrocyte insulin receptor characteristics.
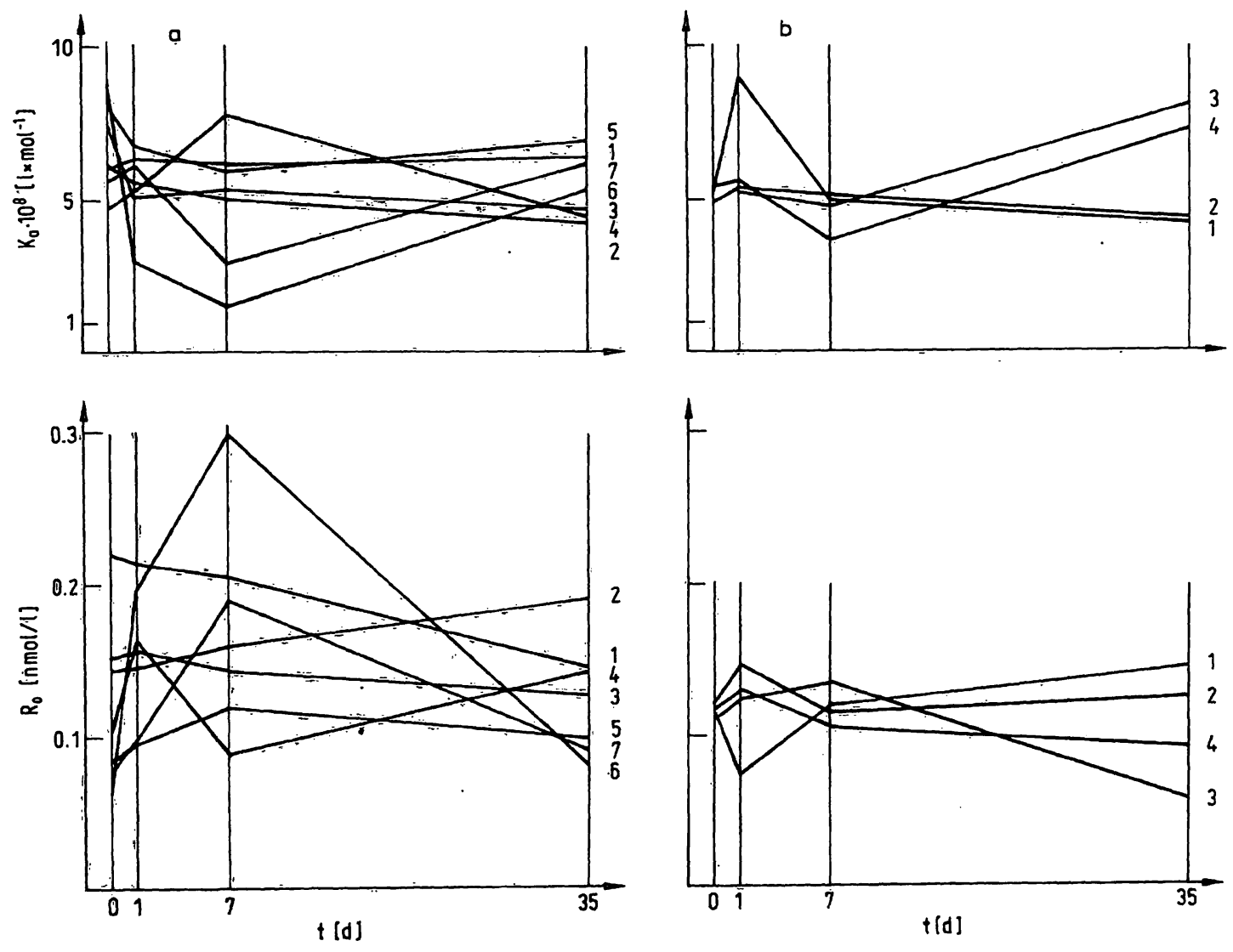

Fig. 2. Affinity $\left(\mathrm{K}_{\mathrm{a}}\right)$ and concentration $\left(\mathrm{R}_{0}\right)$ of the erythrocyte insulin receptors before $(0)$ and after $(1,7,35$ days) administration of $2 \times 60 \mathrm{mg} \mathrm{16-methyleneprednisolone} \mathrm{for} 7$ males (a) and for 4 females (b): 

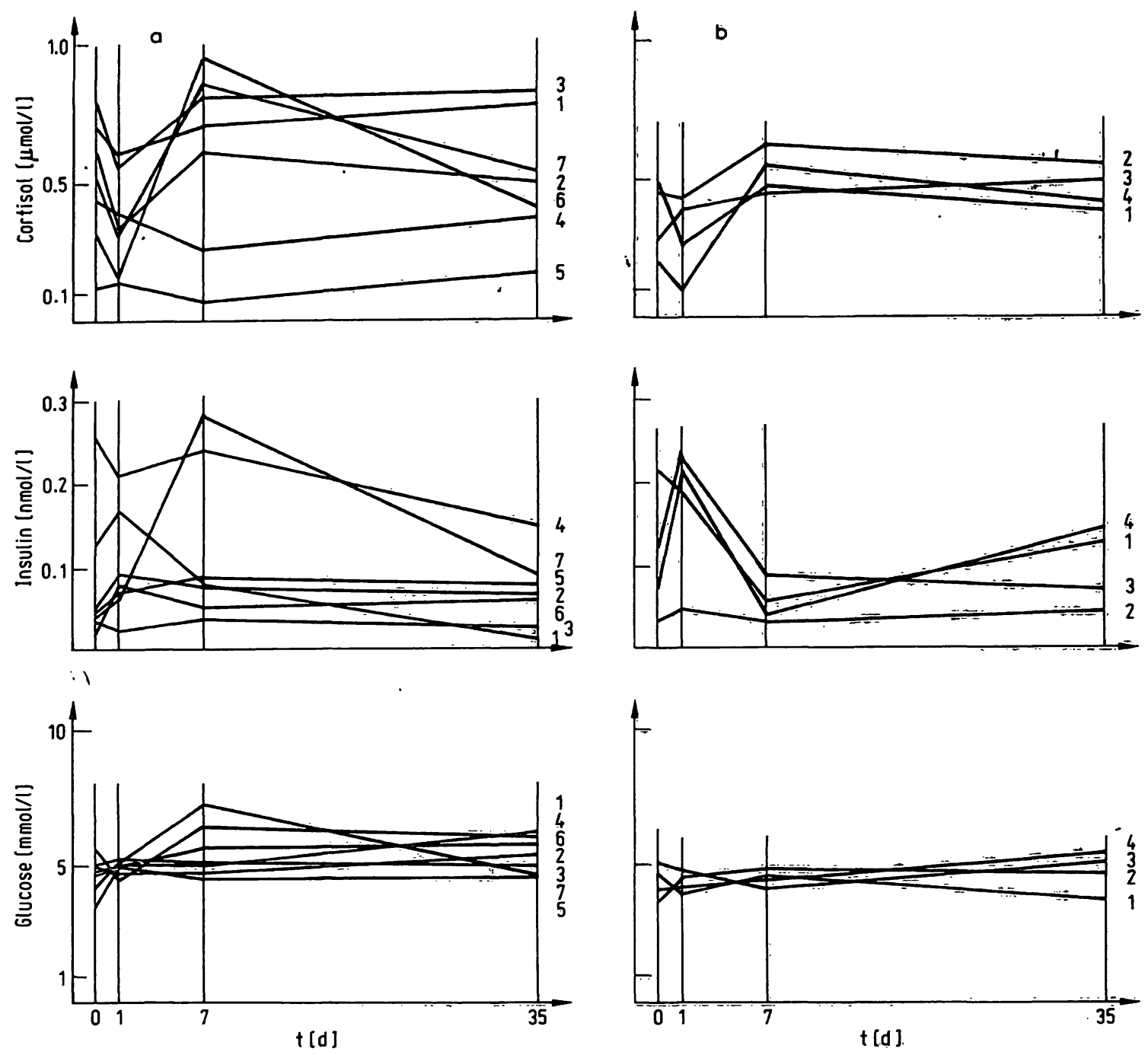

Fig. 3. Plasma cortisol, insulin and glucose concentrations before $(0)$ and after $(1,7,35$ days) administration of $2 \times 60 \mathrm{mg} 16$-methyleneprednisolone for 7 males (a) and for 4 females (b).

\section{References}

1. Munck, A. (1971) Perspect. Biol. Med. 14, 265-289.

2. Olefsky, J. M., Johnson, J., Liu, F., Jen, Ph. \& Reaven, M. (1975) Metabolism 24, 517-526.

3. Beck-Nielsen, H., De Pirro, R. \& Pedersen, O. (1980) J. Clin. Endocrinol. Metab. 50, 1-4.

4. Dwenger, A., Mitzkat, H.-J., Holle, W., Tost, P. \& Trautschold, I. (1982) J. Clin. Chem. Clin. Biochem. 20, 273-279.

5. Yasuda, K. \& Kitabchi, A. E. (1980) Diabetes 29, 811-814.
6. Gambhir, K. K., Archer, J. A. \& Bradley, C. J. (1978) Diabetes 27, 701-708.

7. Dwenger, A., Tost, P. \& Trautschold, I. (1977) J. Clin. Chem. Clin. Biochem. 15, 593-602.

8. Dwenger, A., Tost, P. \& Trautschold, I. (1982) Fresenius' Z. Anal. Chem. 311, $471-472$.

9. Fantus, G., Ryan, J., Hizuka, N. \& Gorden, P. (1981) J. Clin. Endocrinol. Metab. 52, 953-960.

Dr. rer. nat. Alex Dwenger Abteilung für Klinische Biochemie Zentrum Biochiemie

Medizinische Hochschule Hannover

Karl-Wiechert-Allee 9

D-3000 Hannover 61 